\title{
A Poet for All Seasons ${ }^{1}$
}

\author{
DANIEL HUGO \\ Research fellow \\ University of the Free State \\ Departement Afrikaans en Nederlands, Duits en Frans \\ Fakulteit Geesteswetenskappe \\ Universiteit van die Vrystaat \\ Posbus 339 \\ Bloemfontein 9300 \\ South Africa \\ danielhugo@webmail.co.za
}

\begin{abstract}
This is a translation of a general introduction to an anthology of poetry by Olga Kirsch. Major themes and motifs of her work are outlined, as well as a short biography of the authoress is presented. The selection from the poems of Olga Kirsch was published to celebrate her 70th birthday on 23rd of September 1994 as Nou spreek ek weer bekendes aan: 'n Keur 1944-1983 [Now I'm Again Addressing Familiar Ones: A Selection 1944-1983]. For the purposes of the translation the ending of the original introduction has been altered.
\end{abstract}

Keywords: Olga Kirsch; Afrikaans literature; Afrikaans poetry; women's writing

When Olga Kirsch published her first collection of poetry in 1944, she was particularly young. On the twenty-third of September of that year she turned 20. In addition she was only the second women poet to publish in Afrikaans. And she was Jewish. These biographical facts had a defining influence on her poems.

\footnotetext{
${ }^{1}$ Olga Kirsch, Nou spreek ek weer bekendes aan: 'n Keur 1944-1983, uitgesoek en ingelei deur Daniel Hugo. Op 23 September 1994 uitgegee by geleentheid van die sewentigste verjaardag van Olga Kirsch. Human \& Rousseau, Kaapstad, 1994.
} 
Her youthfulness could have contributed to the fact that she was strongly influenced by the generation of poets before her - the Poets of The Thirties. The word and image choices in nearly all the poems in Die Soeklig [The Search Light] are heavily influenced by the Louw poets, the brothers N.P. van Wyk and W.E.G: melancholic expressions of emotions intertwined with adjective rich nature descriptions that teem with e-endings ("blanke stamme," "dorre blare," "dounatte wange," "klare dag," etc). The most convincing example of this kind of adolescent imitation is "Die jonge moeder" [The Young Mother]. It is an Italian sonnet that carefully follows the text book rules, though with surprising skill. Between the romantic sensitivities of a yearning heart and a martyred soul there are some lines that will strike the contemporary reader with their pared down sobriety:

Afskeid, afskeid bring vaal vlae waar wit wolke was; waar stilte was, leemte.

\author{
Farewell, farewell brings \\ ashen gusts where white clouds were; \\ where silence was \\ emptiness.
}

These four lines predict the tighter, suggestive use of language of the following volumes.

Also the poem "Die voetsoldaat" [The Infantryman] in Die soeklig is more sober and substantial than the verses surrounding it. Furthermore, this poem makes the year of publication of this collection relevant. It was the penultimate year of the Second World War. From the untitled opening poem it appears that the poet's beloved has also gone to war. With this subject matter - that in her second volume of 1948, Mure van die hart [The Walled-in Heart / Walls of the Heart], is exploited even further - Olga Kirsch brings something new to Afrikaans poetry. Uys Krige's Oorlogsgedigte [War Poems] had already appeared in 1942, but she became the first to write about the feelings of the woman left behind.

That Kirsch should find a special connection to Elisabeth Eybers is obvious. She was the only woman forerunner in Afrikaans and, like Kirsch, she was very young - twenty-one years old - when she first published. By 1944 Eybers had already published two volumes: Belydenis in die skemering [Confessions in the Twilight], in 1936, and Die stil avontuur [The Quiet Adventure], in 1939. It was a wholesome influence, as is clearly deducted from "Illusie" [Illusion], the best poem in Die soeklig. Critics would also point to correlations with Eybers in her later collections with regard to verse techniques (a preference for couplets, quatrains and sonnets) and to subject (mother- and grandmotherhood, displacement, love between older people, remembrances of mother and father, finely drawn nature descriptions). Yet one cannot confuse the work of these two poets: each 
has an individual accent, which in later years becomes more prominent by their living permanently abroad. With Eybers it is a Dutch accent with Lowlands geographical and languages markers - with Kirsch an Israeli accent characterised by Middle Eastern geographical markers (such as her poems about Jerusalem, the Negev Desert, the Galilee, etcetera).

The most important biographical fact about the poetry of Kirsch is that she was a Jew. In the first instance it explains her interest and involvement in - as a result of a beloved who was a soldier - the Second World War. According to a poem in Die soeklig she was one of those people who, during the forties, daily studied the newspapers ("daagliks in the koerante tuur"). The devastating results that the war had for the Jews is well known. It also explains her Zionist (Jewish Nationalist) longings in her second volume for Palestine as lost fatherland. I am of the opinion that this theme was already present in her first collection, disguised as a lover's desire in the poem "Daar mag net een gebed, één bede wees" ("there may be only on prayer, one supplication"):

... Dat ons in onse tyd,

en ander van die komende geslagte,

die wonder mag herwin van groot geluk

van liefde wat ontplooi in maanblou nagte;

van gulde sonlig wat die siel verruk,

sonder die kanker van onsekerheid.

\author{
... That we in our time, \\ and others of the coming generations, \\ may regain the wonder of great happiness \\ of love that unfolds in moon-blue nights; \\ of golden sunlight that enchants the soul, \\ without the cancer of uncertainty.
}

In the weekly Die Huisgenoot of $21^{\text {st }}$ June 1946, together with the "Twee Paasgesange" [Two Passover Songs], two "Palestynse sange" [Palestinian Songs] also appeared. However, these two sonnets ("Lied van die terroriste" [Song of the Terrorists] and "Voor die vuurpeloton" [Facing the Firing Squad]) were not included in Mure van die hart. "Voor die vuurpeloton" is good enough to save from being forgotten:

\section{Facing the Firing Squad}

Blindfold him now and lead him to the wall

which is the last support his narrow shoulders

have upon this earth. How can one weep

for him who proudly awaits his finest hour.

With cold fingers interlaced

and lips in thin line pressed together

he calls his people and know they hear his voice -

a soundless cry, yet mightier than sound. 
And in the heart that without hesitation sacrificed his youth and years

from an abundance of love, beats only

the desire to make this one last sacrifice.

Let the burning bullet cleave his flesh in song

that he might die and Israel live again!

In 1948, during the War of Independence, she emigrated to Israel. There she married the mathematician Joseph Gillis. In their hometown of Rehovot she taught English - first as teacher and later as university lecturer. (In South Africa she obtained an Honours degree in Afrikaans and Dutch, and in Israel an MA in English literature). Since her departure she visited South Africa only three times: in 1975 for the Afrikaans Language Festival; in 1979 on the occasion of the Afrikaans radio service's book auction, and in 1981 to see her ill mother for the last time. With the 1975 visit she also visited her birthplace, Koppies in the Free State Province - compare the poem "Die tuin is kaal..." [The Garden Is Bare...] in Geil gebied [Lush Land]. She had two daughters, born in 1950 and 1953 respectively. With her husband, who died in November 1993, she had to speak English; with her daughters Hebrew.

As member of a nation who through the centuries has known repression and persecution, Olga Kirsch had greater sensitivity for racial discrimination in South Africa than her fellow South Africans. This sensitivity was the inspiration for her group of poems "Die blokhuis" [Blockhouse] in Mure van die hart. In this respect she was preceded by S.V. Petersen who also debuted as a poet in 1944. "Teater" [Theatre] in Geil gebied testified to her continued concern with regard to this issue. Her political attention was - naturally - held in the later volumes by the problems of her new fatherland. As in the following, shrill verse from Oorwinteraars in die veemde [Overwintering in Exile]:

Dalk kom sy nooit tot ewewig, dalk gaan ons droewig in lengte van dae aan haar gebind deur angs, soos ouers aan 'n mislukte kind te swak om ooit'n eie weg te baan.

Die volke wil nie aan ons die rus toestaan wat hul besit; straatbendes met die kreet "Hierosolyma est perdita" gereed en gretig altyd en oral om dood te slaan te brand en plunder sondat ons naam vergeet mag raak. O mag Jerusalem bly staan!
Perhaps she will never come to equilibrium, maybe we will be sadly bound to her in length of days through anxiety, like parents to a failed child too weak to ever find his own way.

The nations do not want to grant us the peace that they possess; street gangs with the cry "Hierosolyma est perdita" are ready and anxious to kill without concern for time and place to burn and loot so that our name may be forgotten. Oh may Jerusalem remain standing! 
After her emigration Olga Kirsch's poetical voice was silent for 24 years. She was silent in Afrikaans - the language of her youth environment in the Free State. She was silent in English ${ }^{2}$ - the language of her mother and education at Eunice Girls' High School in Bloemfontein and at the University of the Witwatersrand. She was silent in Hebrew - the new language of the new state which she had to learn. Then, in 1972, out of the blue her third collection with the humble title Negentien gedigte [Nineteen Poems] appeared. The volume opens with these suitable words: "Ek weet wat droogte is" - "I know what drought is." Two years before that a promising little cloud had appeared in the sky when she published in the magazine Buurman Afrikaans translations of Hebrew poems by the Israeli Leah Goldberg. In June 1971 in the same magazine two poems, which were not included in Negentien gedigte, were published ("Sesdaagse oorlog" and "By die lees van Solzhenitsyn"). These verses were apparently finger exercises for her 'second debut.'

With regard to her father who immigrated from Lithuania to South Africa, she says in Negentien gedigte "...ek het my geskaam vir jou spraak / wat in twee vreemde tale vreemd gebly het." ("I was embarrassed by your accent / that remained foreign in two foreign languages") These two foreign languages were English and Afrikaans. He was a Yiddish speaker. These lines about her father are echoed in Oorwinteraars in die vreemde when she addresses her husband: "Steeds bly ons vreemdelinge vir mekaar se tale" ("Still we remain strangers to each other's languages") - referring to the symbolic language of his field of research and the Afrikaans of her poetry. To keep her Afrikaans alive in Israel was a battle. In an interview published in the South African daily Beeld on the $11^{\text {th }}$ August 1979, she said:

[...] to write is a necessity, but it is becoming increasingly demanding for me to write in Afrikaans. When I write in Afrikaans, I must immerse myself in Afrikaans. For example, I exclusively read Afrikaans articles, newspapers and literature. It is simply becoming too much of an effort it disturbs my peace [...] Afrikaans is the language of my childhood and youth, of friends and a rural school. It is stronger than the English of my parents' home. However, I would like to write in Hebrew. I have tried, but the critics say it reads like a translation.

Eventually she gave up the battle. In a letter to me (dated $24^{\text {th }}$ January 1994) she writes: "I am no longer writing in Afrikaans - over the last years it has become impossible for me. Now I am writing in English." Her poetic competence in English was already noted in 1948 when she was co-translator of Elisabeth Eybers's poems in The Quiet Adventure.

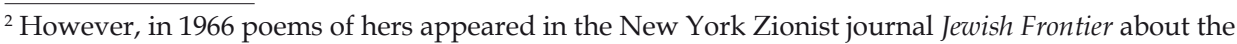
First War of Independence (D.H. - June 1994).
} 
The Jewish themes plus the self-confident own voice makes Mure van die hart one of the three highlights of Kirsch's oeuvre. The other two are Geil gebied [Lush Land] of 1976 and Ruie Tuin [Overgrown Garden] of 1983 - her last volume. As the titles suggest, she conquered the word-desert in these two collections. The desire expressed in the opening verse of Negentien gedigte was abundantly fulfilled.

Waai uit die weste, wind en bring die reën en vul die put en laat die wynstok rank; kom westewind, bring rede om te seën om te bedank.

\author{
Blow from the west, \\ wind and bring the rain \\ and fill the well and let the vine grow; \\ come west wind, bring reason to bless \\ to give thanks.
}

Negentien gedigte (1972) and Oorwinteraars in die veemde (1978) however make less of an impression, while Afskeide [Farewells] of 1982 - elegiac verses about her mother and her family history - are too prosaic and personal to succeed as poetry. In 1992 in Israel a collection of English poems, The Book of Sitrya, was published. It deals with her ten-year old granddaughter who died of a mysterious disease. I quote a single poem as example:

Nobody understood

what had maimed in the cushioning womb

and companioned you to pain.

They called you Sitrya,

Secret of God.

The butterfly syllables skip

like the blithe child you became,

but under the ripple of the name

glints the chill seaward current:

God's secret, you came and went.

Afrikaans poetry has been endlessly enriched by its 'exile' poets: Elisabeth Eybers, Breyten Breytenbach, Barend J. Toerien, P.J. Philander, Julian de Wette, Sheila Cussons. Olga Kirsch was more than simply one 'overwintering in exile;' she was a poet for all seasons.

Daniel Hugo

April 1994

Translation: Marlene Malan and Egonne Roth 